\title{
ANALISA PENGARUH PERBEDAAN DOSIS GULA TERHADAP TEKSTUR DENGAN METODE ANOVA SATU ARAH SERTA PENENTUAN DOSIS TERBAIK DENGAN METODE AHP DAN ANALISA KUALITAS DENGAN METODE QUALITY FUNCTION DEPLOYMENT PADA PRODUK MANISAN TOMAT
}

\author{
CHRISWAHYUDI ${ }^{1)}$, \& TYAS EKA KURNIA ${ }^{2)}$ \\ ${ }^{1,2)}$ Program Studi Teknik Industri, Fakultas Sains dan Teknologi \\ Institut Sains dan Teknologi Al-Kamal \\ Jl Raya Al-Kamal No 2 Kedoya, Kebon Jeruk Jakarta Barat 11520 \\ Email: chrismb73@gmail.com ${ }^{1)}$,eka.tyaskurnia@gmail.com ${ }^{2)}$
}

\begin{abstract}
ABSTRAK
Manisan tomat sebagai salah satu pengolahan makanan dari bahan tomat dan gula sehingga dapat menjadi solusi alternatif ekonomi bagi petani tomat. Untuk mendapatkan komposisi manisan tomat tepat maka diperlukan penelitian yang terkait dengan analisa pengaruh perbedaan dosis gula terhadap pengujian tekstur manisan tomat dengan metode Anova satu arah. Untuk mengetahui dosis gula yang terbaik dengan menggunakan metode pendekatan AHP. Untuk menetapkan spesifikasi kebutuhan dan keinginan konsumen didapat dengan menggunakan metode QFD. Hasil dari penelitian ini menunjukkan bahwa dosis gula yang berbeda mempengaruhi tekstur manisan tomat. Hasil analisa dari penelitian ini menunjukkan bahwa dosis gula terbaik adalah 25\%. Hasil analisa matriks House of Quality didapat bahwa keinginan terbesar konsumen terhadap produk manisan tomat adalah rasa manis, tekstur kenyal / tidak lembek dengan bobot kepentingan 207. Untuk respon kebutuhan teknis terbesar berdasarkan keinginan konsumen adalah harga Rp. 15.000,- per kemasan 250 gram. harga tersebut sesuai penelitian dapat dijangkau di kalangan masyarakat dengan bobot kolom 4563.
\end{abstract}

Kata Kunci: Manisan tomat, ANOVA, AHP dan QFD.

\section{PENDAHULUAN}

Tanaman tomat (Solanum lycopersicum

L.) telah lama dibudidayakan oleh petani Indonesia, baik di dataran rendah maupun dataran tinggi. Tomat dapat tumbuh hampir di seluruh wilayah di Indonesia. Menurut laporan dari Badan Pusat Statistik, sentra pertanaman tomat di Indonesia terpusat di Pulau Jawa. Luas panen pertanaman tomat pada tahun 2015 secara nasional mencapai 54.544 ha dengan produksi total sebesar 877.792 ton serta produktivitas 16,09 ton/ha (Badan Pusat Statistik, 2015).

Saat musim panen di Indonesia hasil panen tomat berlimpah sehingga mengakibatkan harga tomat menurun, ditambah lagi dengan umur simpan tomat yang tidak lama mengakibatkan banyak petani tomat seringkali mengalami kerugian saat musim panen telah datang, hal ini perlu dilakukan evaluasi dan pemanfaatan olahan tomat, salah satunya menjadi produk manisan tomat

Manisan tomat adalah salah satu terobosan pemanfaatan hasil dari buah tomat yang bertujuan untuk manambah umur simpan dari buah tomat. Selain rasanya yang manis, tekstur yang kenyal, serta bentuk dan warna menyerupai kurma, manisan tomat akan menambah nilai jual karena tomat tidak hanya diolah sebagai masakan sayur tetapi juga dapat menjadi olahan makanan ringan yang siap dikonsumsi kapan saja.

Bahan utama pembuatan manisan tomat adalah tomat itu sendiri dan gula pasir. Penambahan gula berfungsi sebagai pengawet alami dari produk manisan tomat, selain itu gula juga membantu memperbaiki warna, rasa manis dan tekstur dari manisan tomat. Untuk 
mendapatkan warna, rasa dan tekstur manisan tomat yang sesuai tentunya diperlukan penambahan gula dengan dosis yang tepat dalam pembuatannya.

\section{METODOLOGI}
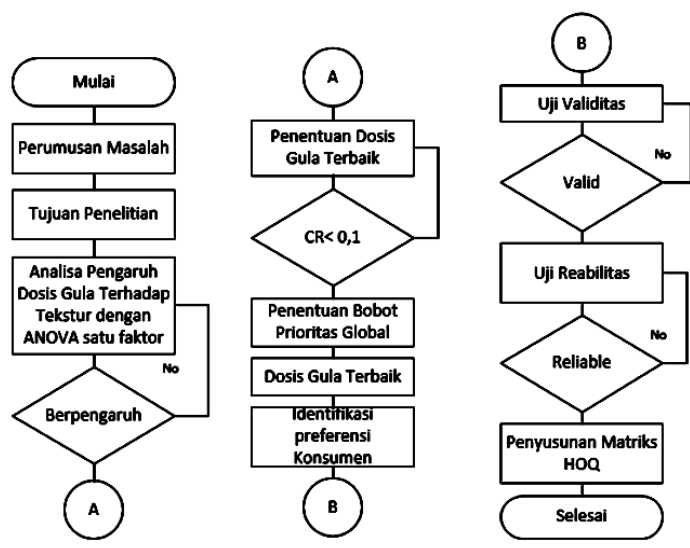

Gambar 1. Flowchart Penelitian

\section{HASIL DAN PEMBAHASAN}

\section{Bahan dan Cara Pembuatan}

Bahan-bahan yang digunakan dalam penelitian ini adalah sebagai berikut:
a. Tomat
b. Gula pasir
c. Kapur Sirih

Berbagai jenis dosis gula pasir merupakan level dari penelitian ini. Dengan demikian berarti dalam perancangan eksperimen yang dilakukan menggunakan 1 faktor yaitu 'dosis gula' dan menggunakan 5 level yaitu 10\%, 15\%, 20\%, 25\% dan 30\%.

Adapun urutan cara kerja eksperimen ini dapat dilihat pada gambar 1 dibawah ini:

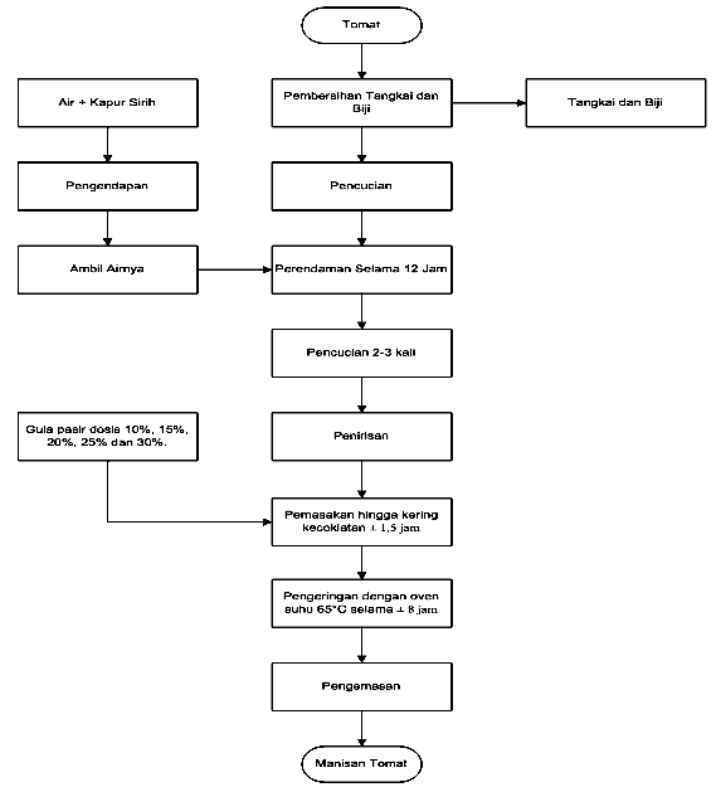

Gambar 2. Flow Chart Pembuatan Manisan Tomat

\section{Pengujian Dengan Metode ANOVA (Analysis of Variance) Satu Arah}

Dalam perancangan eksperimen ini replikasi yang digunakan sebanyak 5 kali. Replikasi ini dirasa cukup atas dasar:

$$
\text { d. } \mathrm{k}=(\mathrm{t}-1)(\mathrm{r}-1) \geq 15
$$

dimana:

$$
\begin{aligned}
\mathrm{t} & =\text { treatment (perlakuan) } \\
\mathrm{r} & =\text { replikasi }
\end{aligned}
$$

dimana:

$(5-1)(5-1) \geq 15$

$16 \geq 15$

Adapun data hasil analisa tekstur dengan menggunakan 5 dosis gula yang berbeda dan replikasi sebanyak 5 kali pada tabel 1

Tabel 1 Data Urutan Random dan Replikasi Analisa Tekstur

\begin{tabular}{|c|c|c|l|c|}
\hline $\begin{array}{c}\text { Dosis } \\
\text { Gula (\%) }\end{array}$ & $\begin{array}{c}\text { Urutan } \\
\text { Penomoran }\end{array}$ & $\begin{array}{c}\text { Urutan } \\
\text { Random }\end{array}$ & $\begin{array}{l}\text { Tekstur } \\
(\mathbf{K g})\end{array}$ & Replikasi \\
\hline 10 & 1 & 11 & 9,332 & 1 \\
\hline 15 & 2 & 2 & 16,571 & 4 \\
\hline 20 & 3 & 23 & 34,264 & 5 \\
\hline 25 & 4 & 10 & 45,25 & 3 \\
\hline 30 & 5 & 22 & 57,87 & 2 \\
\hline 10 & 6 & 9 & 9,522 & 3 \\
\hline 15 & 7 & 12 & 16,096 & 3 \\
\hline 20 & 8 & 14 & 32,634 & 1 \\
\hline 25 & 9 & 8 & 44,988 & 4 \\
\hline 30 & 10 & 3 & 57,595 & 5 \\
\hline 10 & 11 & 13 & 9,025 & 5 \\
\hline 15 & 12 & 20 & 16,582 & 2 \\
\hline 20 & 13 & 7 & 34,261 & 3 \\
\hline 25 & 14 & 19 & 45,214 & 1 \\
\hline 30 & 15 & 1 & 56,959 & 3 \\
\hline 10 & 16 & 21 & 8,952 & 4 \\
\hline 15 & 17 & 15 & 16,012 & 1 \\
\hline 20 & 18 & 6 & 34,895 & 4 \\
\hline 25 & 19 & 18 & 45,197 & 2 \\
\hline 30 & 20 & 24 & 57,782 & 1 \\
\hline 10 & 21 & 4 & 8,929 & 2 \\
\hline 15 & 22 & 17 & 16,468 & 5 \\
\hline 20 & 23 & 25 & 34,524 & 2 \\
\hline 25 & 24 & 5 & 45,358 & 5 \\
\hline 30 & 25 & 16 & 57,081 & 4 \\
\hline & & & & \\
\hline
\end{tabular}

Model perancangan eksperimen yang digunakan untuk mengolah data diatas yaitu dengan metode ANOVA (Analysis of Varian$c e$ ), dengan Hipotesa sebagai berikut:

$\mathrm{H}_{0}=$ Dosis gula yang ditambahkan tidak mempengaruhi hasil uji tekstur pada manisan tomat.

$\mathrm{H}_{1}=$ Dosis gula yang ditambahkan mempengaruhi hasil uji tekstur pada manisan tomat.

\section{Uji Normalitas}

Pengujian normalitas dilakukan dengan menggunakan pengujian grafik P-P Plot pada aplikasi minitab untuk pengujian residual model regresi, grafik bisa dilihat pada gambar 
berikut:

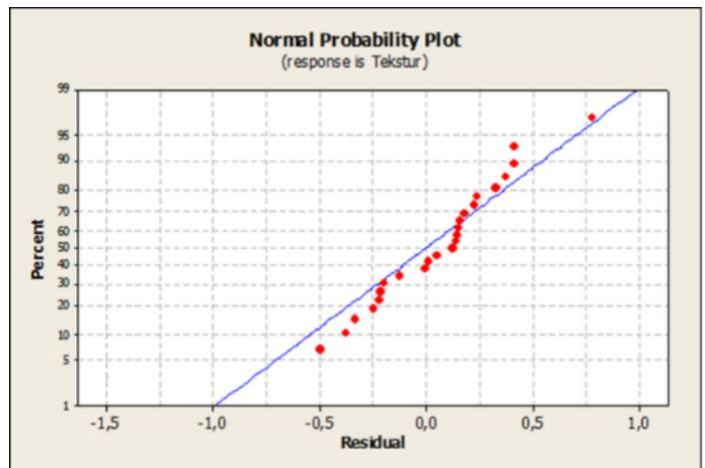

Gambar 2. Grafik Distribusi Normal Hasil Perhitungan ANOVA dengan Software Minitab.

Penyebaran data mengikuti garis dengan demikian dapat disimpulkan bahwa data dari hasil eksperimen ini berdistribusi normal.

\section{Perhitungan Data dengan metode ANO- VA Satu Arah}

Dari penelitian ini terdapat 1 faktor yaitu dosis gula. 5 Level yaitu 10\%, 15\%, 20\%, $25 \%$ dan $30 \%$. Dan replikasi sebanyak 5 kali di tiap levelnya.

Tabel 2. ANOVA Satu Arah dengan Software Minitab

\begin{tabular}{|l|l|l|c|l|c|}
\hline \multicolumn{1}{|c|}{ Source } & DF & \multicolumn{1}{c|}{ SS } & MS & \multicolumn{1}{c|}{ F } & P \\
\hline Dosis Gula & 4 & 7964,422 & 1991,106 & 9175,19 & 0,000 \\
\hline Error & 20 & 4,34 & 0,217 & - & \\
\hline Total & 24 & $7.968,762$ & - & - & \\
\hline
\end{tabular}

Dari tabel Anova satu arah hasil uji tekstur diatas, maka dapat diperoleh nilai untuk F0 $=9175,604$, sedangkan nilai dari $\mathrm{F}$ Tabel diatas diperoleh dari melihat Tabel Nilai Distribusi F, dengan ketentuan sebagai berikut ;

$\mathrm{F}$ tabel $=\mathrm{F} \alpha ; \mathrm{a}-1 ;(\mathrm{n}-\mathrm{a})$

$$
\begin{aligned}
& =\mathrm{F} 0.05 ; 4 ; 20 \\
& =2,87
\end{aligned}
$$

Diperoleh nilai $\mathrm{F}$ tabel $=2,87$ dan nilai $\mathrm{F} 0=9175,604$. Maka untuk kesimpulan yang pertama bahwa nilai $\mathrm{F} 0>\mathrm{F}$ tabel, dengan begitu berarti tolak $\mathrm{H} 0$ (terima $\mathrm{H} 1$ ) yaitu perbedaan dosis gula yang ditambahkan mempengaruhi tekstur pada manisan tomat.

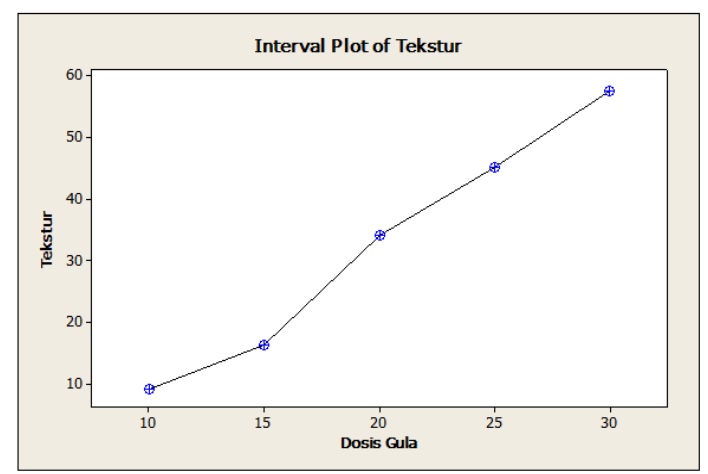

Gambar 3. Grafik Distribusi Interval Plot Tekstur Manisan Tomat

Dari grafik diatas dapat dilihat plot hasil analisa tekstur manisan tomat dari dosis gula $10 \%, 15 \%, 20 \%, 25 \%$ dan $30 \%$ menunjukkan hasil yang berbeda. Maka dapat disimpulkan bahwa semakin besar dosis gula yang ditambahkan maka hasil analisa teksturnya semakin tinggi atau tekstur semakin keras

\section{Penentuan Dosis Gula Terbaik dengan Metode AHP (Analytical Hierarchy Pro- cess) \\ Dalam pemilihan dosis gula pada ma-} nisan tomat disusun dalam 3 (tiga) level hirarki. Level pertama (1) merupakan tujuan pemilihan dosis gula pada manisan tomat, level kedua (2) merupakan kriteria dalam pemilihan dosis gula pada manisan tomat, yaitu warna, takstur, rasa, harga dan waktu pemasakan, sedangkan level ketiga (3) merupakan alternatif dosis gula yaitu $10 \%$, $15 \%, 20 \%, 25 \%$ dan 30\%, adapun hirarki yang diperoleh dapat dilihat pada gambar 4 .

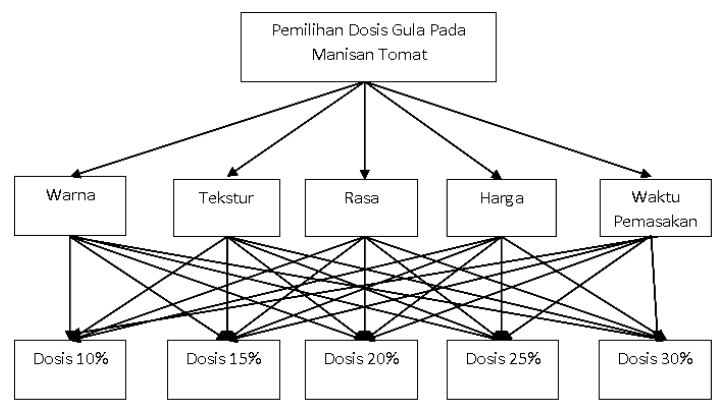

Gambar 4. Struktur Hirarki Masalah

\section{Data Hasil Penilaian Pemilihan Kriteria Manisan Tomat}

Hasil pengolahan data penilaian pemilihan kriteria manisan tomat didapat matriks perbandingan berpasangan dalam pemilihan kriter-ia dosis gula. 
Tabel 3. Matriks Perbandingan Berpasangan Dalam Pemilihan Kriteria Dosis Gula

\begin{tabular}{|c|c|c|c|c|c|}
\hline Kriteria & Warna & Tekstur & Rasa & Harga & Waktu \\
\hline Warna & 1 & 0,441 & 0,262 & 3,390 & 3,323 \\
\hline Tekstur & 2,268 & 1 & 0,616 & 4,129 & 3,390 \\
\hline Rasa & 3,817 & 1,623 & 1 & 5,903 & 6,188 \\
\hline Harga & 0,295 & 0,242 & 0,169 & 1 & 2 \\
\hline Waktu & 0,301 & 0,295 & 0,162 & 0,5 & 1 \\
\hline Total & 7,681 & 3,601 & 2,209 & 14,922 & 15,901 \\
\hline
\end{tabular}

Hasil perhitungan bobot prioritas Perbandingan Berpasangan Kriteria Dalam Pemilihan Dosis Gula

Tabel 5. Prioritas Kepentingan (Bobot) Kriteria Dalam Pemilihan Dosis Gula

\begin{tabular}{|c|c|c|c|c|c|c|}
\hline Kriteria & Warna & Tekstur & Rasa & Harga & Waktu & $\begin{array}{c}\text { Bobot } \\
\text { Prioritas }\end{array}$ \\
\hline Warna & 0,130 & 0,122 & 0,119 & 0,227 & 0,209 & 0,161 \\
\hline Tekstur & 0,295 & 0,278 & 0,279 & 0,277 & 0,213 & 0,268 \\
\hline Rasa & 0,497 & 0,451 & 0,453 & 0,396 & 0,389 & 0,437 \\
\hline Harga & 0,038 & 0,067 & 0,077 & 0,067 & 0,126 & 0,075 \\
\hline Waktu & 0,039 & 0,082 & 0,073 & 0,034 & 0,063 & 0,058 \\
\hline \multicolumn{6}{|c|}{ Total } & 1,000 \\
\hline
\end{tabular}

7. Pengujian Konsistensi Terhadap Kriteria Dosis Penambahan Gula

1. Menghitung Eigen Vector dan Eigen Value kriteria

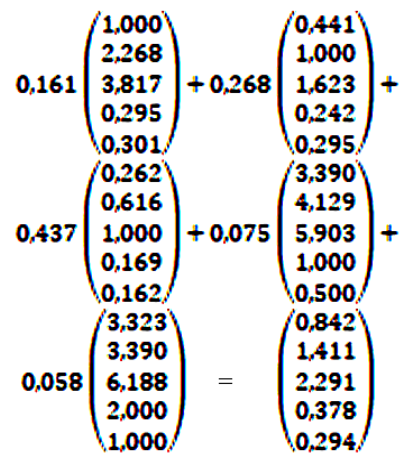

Menghitung eigen value didapat dengan membagi nilai hasil eigen vector dengan bobot prioritas, $0,842 / 0,161=$ 5,213

$1,411 / 0,268=5,257$

$2,291 / 0,437=5,244$

$0,378 / 0,075=5,037$

$0,294 / 0,058=5,058$

2. Menghitung $\lambda$ maksimum

Nilai $\lambda$ didapat dengan menjumlahkan nilai eigen value dibagi dengan jumlah kriteria, perhitungannya sebagai berikut: $\lambda_{\text {maksimum }}=(5,213+5,257+5,244+5,037+5$, $162) / 5=5,162$

3. Menghitung Konsistensi Index (CI) Menghitung nilai konsistensi index yang terdiri dari 5 (lima) kriteria, nilai konsis- tensi index yang diperoleh:

$$
\begin{aligned}
& C I=\frac{\lambda_{\text {maksimum }}-n}{n-1} \\
& C I=\frac{5,162-5}{5-1}=\frac{0,162}{4}=0,040
\end{aligned}
$$

4. Menghitung Indeks Random Konsistensi (RI)

Menghitung indeks random konsistensi (RI) dengan jumlah ordo matriks 5 (lima), $\mathrm{n}=$ $5, \mathrm{RI}=1,12$.

Tabel 6. Random Indeks (RI)

\begin{tabular}{|c|c|c|c|c|c|c|c|c|c|c|}
\hline $\mathrm{N}$ & 1 & 2 & 3 & 4 & 5 & 6 & 7 & 8 & 9 & 10 \\
\hline $\mathrm{RI}$ & 0 & 0 & 0,58 & 0,9 & 1,12 & 1,24 & 1,32 & 1,41 & 1,45 & 1,49 \\
\hline
\end{tabular}

$\mathrm{CR}=\mathrm{CI} / \mathrm{RI}=0,040 / 1 \cdot 12=0,036<0,1$

Karena CR $<0,1$ berarti preferensi responden adalah konsisten.

\section{Data Hasil Perbandingan Dosis Gula Berdasarkan kriteria}

Hasil perhitungan perbandingan dosis gula untuk masing masing kriteria ditampilkan dalam grafik dibawah ini dimana nilai konsistensi rasio dari semua kriteria masuk dalam kategori konsisten.

Tabel 7. Nilai konsistensi rasio dari dosis gula terhadap kriteria

\begin{tabular}{|l|l|}
\hline \multicolumn{1}{|c|}{ Kriteria } & $\begin{array}{c}\text { Konsistensi } \\
\text { Rasio }\end{array}$ \\
\hline Warna & $0,023<0,1$ \\
\hline Tekstur & $0,009<0,1$ \\
\hline Rasa & $0,008<0,1$ \\
\hline Harga & $0,008<0,1$ \\
\hline Waktu Pemasakan & $0,014<0,1$ \\
\hline
\end{tabular}

\section{Prioritas Global}

Hasil penilaian 5 responden, bobot prioritas total didapat dari hasil evaluasi yang dilakukan terhadap 5 (lima) kriteria yakni yang dikalikan dengan vektor prioritas, maka diperoleh tabel hubungan antara kriteria dan alternatif.

Tabel 8. Matriks Perbandingan Bobot Prioritas Kriteria Dengan Bobot Prioritas Alternatif

\begin{tabular}{|c|c|c|c|c|c|}
\hline Dosis & $\begin{array}{c}\text { Warna } \\
\mathbf{( 0 , 1 6 1 )}\end{array}$ & $\begin{array}{c}\text { Tekstur } \\
\mathbf{( 0 , 2 6 8 )}\end{array}$ & $\begin{array}{c}\text { Rasa } \\
\mathbf{( 0 , 4 3 7 )}\end{array}$ & $\begin{array}{c}\text { Harga } \\
\mathbf{( 0 , 0 7 5 )}\end{array}$ & $\begin{array}{c}\text { Waktu } \\
\text { Pemasakan } \\
\mathbf{( 0 , 0 5 8 )}\end{array}$ \\
\hline $10 \%$ & 0,046 & 0,065 & 0,049 & 0,328 & 0,273 \\
\hline $15 \%$ & 0,13 & 0,078 & 0,096 & 0,332 & 0,348 \\
\hline $20 \%$ & 0,219 & 0,219 & 0,289 & 0,185 & 0,222 \\
\hline $25 \%$ & 0,505 & 0,485 & 0,398 & 0,102 & 0,104 \\
\hline $30 \%$ & 0,1 & 0,153 & 0,168 & 0,054 & 0,053 \\
\hline
\end{tabular}


10. Perhitungan prioritas global dari tiap dosis yaitu hasil penjumlahan dari perkalian bobot prioritas alternatif dengan bobot prioritas kriteria

- Dosis $10 \%=0,161(0,046)+0,268$ $(0,065)+0,437(0,049)+0,075(0,328)$ $+0,058(0,273)=0,087$

- Dosis $15 \%=0,161(0,013)+0,268$ $(0,078)+0,437(0,096)+0,075(0,332)$ $+0,058(0,348)=0,129$

- Dosis $20 \%=0,161(0,219)+0,268$ $(0,219)+0,437(0,289)+0,075(0,185)$ $+0,058(0,222)=0,247$

- Dosis $25 \%=0,161(0,505)+0,268$ $(0,485)+0,437(0,398)+0,075(0,102)$ $+0,058(0,104)=0,399$

- Dosis $30 \%=0,161(0,100)+0,268$ $(0,153)+0,437(0,168)+0,075(0,054)$ $+0,058(0,053)=0,138$

Dari hasil perhitungan diatas didapat matriks prioritas global untuk memilih dosis gula terbaik berdasarkan 5 kriteria.

Tabel 9 Matriks Prioritas Global Untuk Memilih Dosis Gula Terbaik

\begin{tabular}{|c|c|c|c|c|c|c|}
\hline Dosis & Warna & Tekstur & Rasa & Harga & $\begin{array}{c}\text { Waktu } \\
\text { Pemasakan } \\
\mathbf{( 0 , 0 5 8 )}\end{array}$ & $\begin{array}{c}\text { Vektor } \\
\text { Prioritas } \\
\text { Global }\end{array}$ \\
\hline $10 \%$ & 0,046 & 0,065 & 0,049 & 0,328 & 0,273 & 0,087 \\
\hline $15 \%$ & 0,13 & 0,078 & 0,096 & 0,332 & 0,348 & 0,129 \\
\hline $20 \%$ & 0,219 & 0,219 & 0,289 & 0,185 & 0,222 & 0,247 \\
\hline $\mathbf{2 5 \%}$ & 0,505 & 0,485 & 0,398 & 0,102 & 0,104 & 0,399 \\
\hline $30 \%$ & 0,1 & 0,153 & 0,168 & 0,054 & 0,053 & 0,138 \\
\hline
\end{tabular}

\section{Uji Validitas dan Reliabilitas}

Hasil uji validitas dan reliabilitas dari 50 responden terhadap 4 pertanyaan mengenai produk manisan tomat yaitu:

Tabel 10. Uji Validitas

\begin{tabular}{|l|c|c|c|}
\hline \multicolumn{1}{|c|}{ Item Pertanyaan } & $\begin{array}{c}\text { r } \\
\text { hitung }\end{array}$ & $\begin{array}{c}\text { r } \\
\text { tabel }\end{array}$ & Keputusan \\
\hline Rasa manis, Tekstur kenyal / tidak lembek & 0,787 & 0,279 & Valid \\
\hline Kemasan berupa toples berbahan plastik & 0,456 & 0,279 & Valid \\
\hline Harga terjangkau dikalangan masyarakat & 0,545 & 0,279 & Valid \\
\hline Mudah didapat di toko terdekat & 0,730 & 0,279 & Valid \\
\hline
\end{tabular}

Sedangkan hasil uji reliabitas nilai $\mathrm{r}$ hitung 0,712 dapat dikatakan ke empat pertanyaan tersebut sangat reliable.

\section{Identifikasi Keinginan Kepentingan Kon- sumen}

Hasil perhitungan bobot kepentingan keinginan konsumen terhadap empat kriteria didapat hasil.
Tabel 11 Hasil Bobot Kepentingan Keinginan Konsumen

\begin{tabular}{|c|l|c|}
\hline No. & \multicolumn{1}{|c|}{ Atribur Keinginan Konsumen } & $\begin{array}{c}\text { Bobot } \\
\text { Kepentingan }\end{array}$ \\
\hline 1 & Rasa manis, Tekstur kenyal / tidak lembek & 207 \\
\hline 2 & Kemasan berupa toples berbahan plastik & 201 \\
\hline 3 & Harga terjangkau dikalangan masyarakat & 173 \\
\hline 4 & Mudah didapat di toko terdekat & 198 \\
\hline
\end{tabular}

13. Kompetisi Penilaian Konsumen (Customer Competitive Evaluation)

Hasil kuesioner perbandingan antara produk manisan tomat (kudato) dengan kurma

Tabel 12 Kompetisi Penilaian Konsumen (Customer Competitive Evaluation)

\begin{tabular}{|c|c|c|c|c|c|c|c|c|c|c|}
\hline \multirow[t]{2}{*}{ No } & \multirow[t]{2}{*}{ Pernyataan } & \multicolumn{4}{|c|}{$\begin{array}{c}\text { Manisan } \\
\text { Tomat }\end{array}$} & \multicolumn{5}{|c|}{ Kurma } \\
\hline & & \begin{tabular}{l|l}
1 & 2 \\
\end{tabular} & \begin{tabular}{l|l|}
2 & 3
\end{tabular} & 4 & 5 & 1 & & & & 5 \\
\hline 1 & Rasa manis, tekstur kenyal / tidak lembek & & $\sqrt{ }$ & & & & & & $\sqrt{ }$ & \\
\hline 2 & Kemasan berupa toples berbahan plastik & & $\sqrt{1}$ & & & & & $\sqrt{ }$ & & \\
\hline 3 & Harga terjangkau dikalangan masyarakat & & $\sqrt{ }$ & & & & & $\sqrt{ }$ & & \\
\hline 4 & Mudah didapat di toko terdekat & $v$ & & & & & & & $\sqrt{ }$ & \\
\hline
\end{tabular}

14. Penyusunan Matriks Hubungan Antara Keinginan Konsumen Dengan Kebutuhan Teknis (Relationship Matrix)

Matriks hubungan digunakan untuk menunjukan dengan grafik derajat pengaruh antara setiap persyaratan teknik dan setiap persyaratan pelanggan

1. Adapun atribut keinginan konsumen

a. Rasa manis, tekstur tidak lembek/kenyal.

b. Kemasan berupa toples berbahan plastik.

c. Harga terjangkau dikalangan masyarakat.

d. Mudah didapat di toko terdekat

2. Adapun atribut Kebutuhan Teknis

$\mathrm{Y} 1$ = Bahan baku utama tomat segar

Y2 = Kualitas bahan baku utama dan pelengkap

Y3 = Komposisi bahan baku

Y4 = Bahan baku alami

Y5 = Proses produksi higienis

Y6 = Tidak menggunakan bahan pengawet

$\mathrm{Y7}=$ Kemasan berbahan dasar plastik

Y8 = Desain label kemasan menarik

Y9 = Informasi label lengkap

Y10 $=$ Manis, tekstur kenyal $/$ tidak lembek

$\mathrm{Y} 11=$ Aroma khas produk

Y12 = Harga terjangkau

Y13 $=$ Produk mudah didapat

Y14 = Produk dapat dikembangkan

Hasil hubungan antara atribut keinginan konsumen dan atribut teknis. 


\section{Relationship}

$\boldsymbol{\Delta}=$ Hubungan yang kuat, bernilai 9

- = Hubungan yang medium, bernilai 3

$0=$ Hubungan yang lemah, bernilai 1

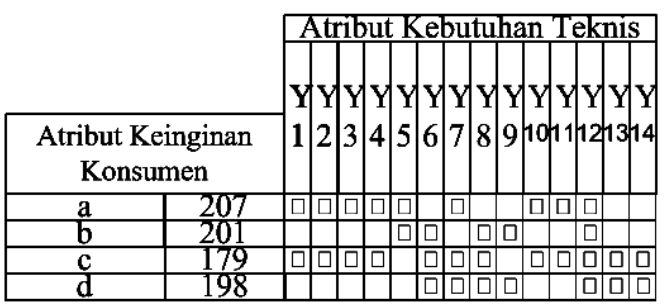

Gambar 5. Matriks Hubungan (Relationship Matrix)

Menentukan Bobot Kolom (Weight Colomn) berdasarkan gambar 5 direkap dalam tabel.

Tabel 13 persentase nilai tertinggi dari bobot kolom

\begin{tabular}{|c|c|c|c|}
\hline No & $\begin{array}{c}\text { Perhitungan Bobot } \\
\text { Kolom }\end{array}$ & $\begin{array}{c}\text { Persentase } \\
\text { (\%) }\end{array}$ & Ranking \\
\hline 1 & 1140 & $3.3 \%$ & 13 \\
\hline 2 & 2382 & $7.09 \%$ & 6 \\
\hline 3 & 2382 & $7.09 \%$ & 7 \\
\hline 4 & 2382 & $7.09 \%$ & 8 \\
\hline 5 & 822 & $2.4 \%$ & 14 \\
\hline 6 & 2526 & $7.5 \%$ & 4 \\
\hline 7 & 2580 & $7.6 \%$ & 3 \\
\hline 8 & 2526 & $7.5 \%$ & 5 \\
\hline 9 & 2007 & $5.9 \%$ & 12 \\
\hline 10 & 2382 & $7.09 \%$ & 9 \\
\hline 11 & 2382 & $7.09 \%$ & 10 \\
\hline 12 & 4563 & $13.5 \%$ & 1 \\
\hline 13 & 3339 & $9.9 \%$ & 2 \\
\hline 14 & 2151 & $6.4 \%$ & 11 \\
\hline
\end{tabular}

\section{Matriks House of Quality}

Penyusunan Matriks of Quality berdasarkan pengolahan data kepentingan keinginan konsumen (importance rating), pengolahan data kompetisi produk (customer competitive evaluation) penyusun persyaratan kebutuhan teknis (technical requirement), penyusun target kebutuhan teknis (operational goal / target), penyusun matriks hubungan antara keinginan konsumen dengan kebutuhan teknis (relationship matrix), penyusunan matriks kolerasi hubungan antar atribut kebutuhan teknis (interrelationship matrix), dan menentukan bobot kolom seperti pada gambar berikut:

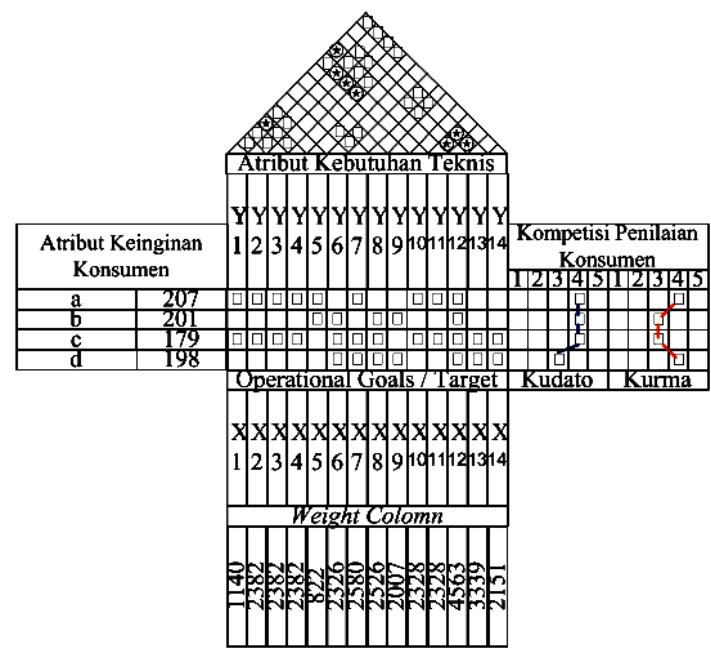

Gambar 6 Matriks House of Quality

\section{KESIMPULAN}

1. Pada perancangan eksperimen dengan metode Anova Satu Arah pada pengujian tekstur pada manisan tomat menyatakan bahwa "dosis gula yang ditambahkan dalam proses pemasakan dapat mempengaruhi hasil pengujian tekstur pada manisan tomat".

2. Pemilihan dosis gula terbaik menggunakan sistem pendukung keputusan metode pendekatan AHP (Analytical Hierarchy Process) pada manisan tomat diperoleh dosis gula terbaik yaitu $25 \%$.

3. Terdapat pernyataan peringkat teratas kepentingan keinginan konsumen (importance rating) rasa manis, tekstur kenyal dan tidak lembek dengan bobot kepentingan 207, kemasan berupa toples berbahan plastik dengan bobot kepentingan 201, mudah didapat di toko terdekat dengan bobot kepentingan 198, dan harga terjangkau dikalangan masyarakat dengan bobot kepentingan 173 .

4. Berdasarkan perhitungan bobot kolom didapat lima nilai teratas yaitu harga $\mathrm{Rp}$. 15.000,- per kemasan 250gram, harga tersebut sesuai penelitian dapat dijangkau dengan nilai bobot kolom 4563, produk tersebar di toko terdekat dengan nilai bobot kolom 3339, menjamin kepercayaan kepada konsumen dengan tidak menggunakan bahan yang tidak mengandung bahan kimia dengan nilai bobot kolom 2580, menggunakan bahan yang terlaminasi dengan PE dan kombinasi warna, gambar, dan tulisan menarik guna mampu menarik perhatian 
konsumen mempunyai nilai bobot kolom yang sama yaitu 2526 .

5. Kekuatan dari produk sendiri terletak pada pernyataan rasa manis, tekstur kenyal / tidak lembek dengan penilaian skor 4 yaitu memuaskan, bahan baku dan pelengkap serta komposisi yang sesuai membuat manisan tomat dapat dinikmati konsumen. Kemasan berupa toples berbahan plastik dengan ppenilaian skor 4 yaitu memuaskan, bahan plastik PE (Poly Ethylene) yang aman digunakan dengan label dan design yang menarik. harga terjangkau dikalangan masyarakat dengan penilaian skor 4 yaitu memuaskan, harga Rp. 15.000,- per kemasan 250 gram terjangkau oleh konsumen. Sedangkan kelemahan dari produk sendiri adalah dari segi mudah didapat di toko terdekat, produk belum banyak tersebar di toko terdekat karena masih dalam proses pengenalan dan pengembangan pemasaran.

\section{DAFTAR PUSTAKA}

Adhitya Wahyu Wicaksono. (2013). Penerapan Metode QFD (Quality Function Deployment) Pada Rencana Pengembangan Sekolah di SMKN 2 Yogyakarta. Laporan Penelitian. UN Yogyakarta

Arsyad, A. 2008. Media Pembelajaran. Jakarta: Raja Grafindo Persada.

Azwar, Saifuddin. 1997. Metode Penelitian. Yogyakarta: Pustaka Pelajar.

Danim, Sudarwan dan Darwis. 2003. Metode Penelitian (Prosedur, Kebijakan dan Etik). Jakarta: Penerbit Buku Kedokteran EGC.

Hicks, C. R. 1982, Fundamental Consepts in the Design of Eksperiment $3^{\text {rd }}$ edition,
New York: Holt-Saunders International Editions.

James. (1991). Quality Function Deployment. Milwaukee

Marimin dan N. Maghfiroh. 2010. Aplikasi Teknik Pengambilan Keputusan dalam Manajemen Rantaii Pasok. Bogor: Penerbit IPB Press

Mintzberg, H. 1973. The Natural of Managerial Work. New York: Harper Collins.

Montgomery, Douglas.C. 2005. Design and Analysis of Exsperiment, 6 ${ }^{\text {th }}$ Ed. John Wiley \& Sons. New York.

Saaty, T.L. 1983. Decision Making For Leaders: The Analytical Hierarchy Process for Decision in Complex World. RWS Publication, Pittsburgh.

Solso R.L. dan Maclin M.K. 2002. Experimental Psychology: A Case Approach $7^{\text {th }}$ edition. Allyn and Bacon, USA.

Subiyanto, Ibnu. 2000. Metode Penelitian Managemen dan Akuntansi. Yogyakarta: UPP AMP YKPN

Sugiyono. 2010. Metode Penelitian Pendidikan (Pendekatan Kuantitatif, Kualitatif, dan $R \& D$ ). Alfabeta: Bandung.

Sukardi. 2003. Metodologi Penelitian Pendidikan (Kompetensi dan Praktiknya). Jakarta: Bumi Aksara.

Suryadi K. dan Ramdhani M.A. 2002. Sistem Pendukung Keputusan. PT. Remaja Rosdakarya. Bandung.

Syaifullah. 2010. Pengenalan Metode AHP (Analytical Hierarchy Process). Lisensi Dokumen; Copyright Februari 2010 Syaifullah08.wordpress.com 